\title{
THE HISTORICAL PROSECUTION OF HATE CRIMES IN THE UNITED STATES OF AMERICA ${ }^{1}$
}

\section{Kamban Naidoo*}

\section{ABSTRACT}

Hate crimes refer to criminal conduct that is motivated by the personal prejudice or bias of the perpetrator. This article examines the laws that were historically used by the American federal government to prosecute hate crimes prior to the passing of a federal hate-crime law. Within the American federal system, the prosecution of crimes is largely left to states that comprise the federation. In the nineteenth century, however, the recalcitrance of states to prosecute racially-motivated hate crimes led to the passing of numerous federal-criminal civil-rights laws which permitted greater federal intervention in the investigation and prosecution of such crimes. Despite the laudable intentions underpinning the enactment of federal-criminal civil-rights laws, these laws were costly to implement and poorly interpreted by the courts. The Civil Rights Act of 1968 which was passed after the Civil-Rights Movement allowed for greater federal intervention in the investigation and prosecution of hate crimes at state and local level. However, the Civil Rights Act of 1968 contained burdensome evidentiary requirements which placed the onus on the prosecution to prove that

1 Since there is no globally-accepted definition of a hate crime, a hate crime can be described as a crime against the person or property that is motivated by the perpetrator's bias or prejudice towards the victim. In crimes against the person, the bias or prejudice could have been directed against a personal characteristic of the victim, such as, inter alia, the victim's race, ethnicity or sexual orientation. In property crimes, the perpetrator's bias or prejudice could have been directed against a personal characteristic of the owner, the possessor or the occupier of the property.

* Senior Lecturer, Department of Criminal and Procedural Law, University of South Africa. 
the victim had been engaged in a federally-protected activity and that the victim's federal rights had been interfered with. It was only in the twenty first century, after the perpetration of two brutal hate crimes that a federal hate-crime law was passed by the American Congress. The Matthew Shepard and James Byrd Junior Hate Crimes Prevention Act of 2009 has facilitated the federal prosecution of hate crimes by removing the evidentiary burdens of the earlier laws and by allowing for increased federal funding and assistance in the investigation and prosecution of hate crimes.

Keywords: Hate crimes; historical prosecution; hate-crime laws; United States of America

\section{Introduction}

Prior to the enactment of a federal hate-crime law in the late twentieth century, the federal government of the United States of America made use of several different laws to prosecute hate crimes. ${ }^{2}$ This article examines the historical background to these laws and their judicial interpretation. The article concludes with a brief examination of the first federal hate-crime law that was enacted by the American federal government in the twenty-first century.

\section{The nineteenth century to the mid-twentieth century: The use of federal-criminal civil-rights laws}

From the nineteenth century to the mid-twentieth century, the American federal government often resorted to the use of federal-criminal civil-rights laws to prosecute racially-motivated crimes when states defaulted by failing to prosecute the perpetrators. Before commencing a discussion of federal-criminal civil-rights laws, however, it is necessary to briefly explain the concept of federalism which is central to the American system of governance.

As opposed to a unitary form of government where a central government authority wields supreme power over all territorial divisions within a state, in a federal system, all exercisable governmental powers are divided between a central, federal government and several state governments. ${ }^{3}$ Within the American federal system, some powers are concentrated in the federal government complemented by other powers vesting in the states which comprise the federation. ${ }^{4}$ The powers

2 There is some consensus that hate-crime laws or laws that specifically criminalise conduct motivated by bias or prejudice were first enacted in the USA in the late twentieth century. See, further, Hall 2013: 20 and Levin 2002: 227.

3 See Zimmerman 1992: 3-4.

4 In reality the position in the USA is more complicated since political authority is divided between the central, national government and more than fifty state governments, and thousands of local governments, counties, municipalities and school districts. See, further, Zimmerman 1992:1. 
that vest in the federal government are limited, enumerated powers since the Tenth Amendment of the American Constitution (1791) reserves powers to the states. ${ }^{5}$ The federal government can consequently enact federal laws only in terms of these limited, enumerated powers. ${ }^{6}$ The powers that are reserved to the states, which are also referred to as "residual powers", include the policing power, and powers that relate to health, safety, morals and the welfare of state citizens. ${ }^{7}$ According to Meese,${ }^{8}$ the intention of the drafters of the American Constitution was for crime and law enforcement to fall largely within the jurisdiction of states. ${ }^{9}$ The federal government therefore has jurisdiction only over a limited number of crimes which include treason, ${ }^{10}$ counterfeiting, ${ }^{11}$ piracy on the high seas and crimes against the law of nations. ${ }^{12}$

In the nineteenth century, however, state and local authorities were reluctant to prosecute crimes that had been perpetrated by Whites against African Americans. ${ }^{13}$ The American Congress therefore passed several federal-criminal civil-rights laws which allowed the federal government greater powers to intervene in raciallymotivated crimes that had been committed at state level. ${ }^{14}$ The origins of modern American hate-crime laws have been traced to these laws which were enacted during the Reconstruction period. ${ }^{15}$ The Reconstruction period refers to the period after the American Civil War when several constitutional amendments were ratified and a number of legal reforms were affected. ${ }^{16}$ The constitutional amendments included provisions for Congress to pass laws which would enforce the amendments at state level and remove the autonomy of states to deprive minorities of their rights. ${ }^{17}$

5 Bradley 1998: 392.

6 Ibid.

7 Sheldon 2002: 81. According to Sheldon, at present, the federal government has slowly usurped what were previously state responsibilities.

8 Meese 1997: 6.

9 A similar view has been expressed by Bradley 1998: 404.

10 United States Constitution, Art III, §3, $\mathrm{Cl} 2$.

11 Idem Art 1 \$8 $\mathrm{Cl} 6$.

12 Idem Art 1 §8 Cl 10 and Riker 1955: 453.

13 The term "African American" is the politically-correct appellation to refer to Americans of African origin. This is the preferred term in this submission. Reference to the older terms, "Negro" and "Black" is, however, unavoidable in a few direct quotations.

14 Jacobs \& Potter 1998: 36. According to Hall 2013: 47, at this point in time, a debate raged between states and the federal government over the control of criminal-law enforcement.

15 This is a view that has been expressed by several American writers including Levin 2002: 227; Hall 1998: 20 and Levin 2009: 7. See, further, Petrosino 1999: 15.

16 The constitutional amendments include the Thirteenth Amendment (1865), which abolished slavery; the Fourteenth Amendment (1868), which granted citizenship to all persons born or nationalised in the USA; and the Fifteenth Amendment (1870), which extended voting rights to citizens who were previously denied the right to vote because of their race, colour or prior status as slaves. See Hall 2013: 21.

17 Hall 2013: 21. Section 5 of the Fourteenth Amendment gave Congress the power to pass any laws necessary to enforce the amendment. 
A number of federal statutes were subsequently passed which supplemented and enforced the constitutional amendments in order to protect newly-freed slaves, particularly in the Southern states, where they were subjected to physical abuse and murder. ${ }^{18}$ Congress passed the Enforcement Act of $1870^{19}$ which aimed to enforce the rights of due process of law and equal protection of the law guaranteed by the Fourteenth Amendment (1868) and the right to vote established by the Fifteenth Amendment (1870). ${ }^{20}$ The Civil Rights Act of $1871^{21}$ permitted the federal government to prosecute persons who conspired to deprive others of their civil rights or to prosecute government agents who deprived persons of their rights. Congress also passed the Ku Klux Klan Act of $1871^{22}$ which expanded the federal government's power to intervene in cases where states failed to protect the constitutional rights of its citizens. ${ }^{23}$ The Ku Klux Klan Act allowed federal authorities to intervene in an enumerated list of activities where there was a conspiracy to violate a civil right, for example, threatening government officers, intimidating witnesses and jurors at a federal trial, interfering with a citizen's right to equal protection under the law and interfering with a citizen's voting rights. These were the most common conspiracies perpetrated by the Ku Klux Klan ${ }^{24}$ against African Americans. ${ }^{25}$ Jacobs and Potter ${ }^{26}$ opine that federal-criminal civil-rights laws were the only option available to the federal government to ensure the investigation and prosecution of crimes perpetrated against former slaves at local and state level. If crimes against former slaves had been investigated and prosecuted by state and local authorities, the enactment of such laws would have been unnecessary.

Despite the laudable federal laws which were passed to protect minority groups, Lawrence ${ }^{27}$ regards these laws as ineffective tools which remained largely unenforced since the Enforcement Act and the Ku Klux Klan Act placed an onerous financial

18 Lawrence 1999: 122. The first civil-rights statute to be passed by Congress was the Civil Rights Act of 1866 (codified as 14 Stat 27-30) which established citizenship for all persons born in the USA.

19 The Enforcement Act of 1870 is codified as 16 Stat 140.

20 Lawrence 1999: 122.

21 The Civil Rights Act of 1871 is codified as 17 Stat 31.

22 The Ku Klux Klan Act of 1871 is codified as 17 Stat 31.

23 Shimamoto 2003-2004: 831.

24 The Ku Klux Klan or "Klan", which is regarded as an organised "hate" group, was formed in 1867 shortly after the American Civil War in the war-ravaged southern states. The "Klan" initially terrorised African Americans by means of cross-burnings and acts of intimidation. See Kelly 1998: 51.

25 According to Lawrence 1999: 122-123, during the congressional debates on the Ku Klux Klan Act, the intention was to have provided federal authorities with the right to intervene in a number of common-law crimes such as murder, arson and robbery which had been committed in states. However the bill was amended and federal prosecution was limited to the specified activities. Thus, rather than a broad, federal hate-crime law, the Ku Klux Klan Act confined federal-criminal jurisdiction only to cases of "rights-interference crimes".

26 Jacobs \& Potter 1998: 36.

27 1999: 123. 
burden on states to protect witnesses. At the time, Congress was unwilling to release additional funds to protect witnesses. ${ }^{28}$ Congress also passed the Civil Rights Act of $1875^{29}$ which may be considered as one of the earliest federal anti-discrimination laws. The Civil Rights Act of 1875 provided for the equal treatment of all races in public-accommodation facilities, transport and places of entertainment.

However, in several cases which mirrored the conservative, prejudicial racial attitudes that were prevalent at the time in the Unites States of America, the United States Supreme Court invalidated several criminal civil-rights statutes or interpreted the laws in a manner that provided no protection to victims from minority groups. ${ }^{30}$ These decisions have been described as the "evisceration" 31 of the Reconstructionera statutory protections and as "the Supreme Court's assault on status-based protections". ${ }^{32}$

In the case of Blyew $v$ United States, ${ }^{33}$ after the murder of an African-American family by two White defendants in the state of Kentucky, the African-American child witnesses were precluded from testifying in state courts. According to the Revised Statute of Kentucky of 1860 which was in force at the time, AfricanAmerican witnesses were prohibited from testifying against Whites. A federal prosecution was subsequently brought under the Civil Rights Act of $1866 .{ }^{34}$ The United States Supreme Court, however, rejected the basis of the indictment since the child witnesses had no standing in federal courts. The court held that the Civil Rights Act of 1866 was intended to protect the rights of the accused and not the rights of victims and witnesses. Levin ${ }^{35}$ refers to the Supreme Court's reasoning in the case of Blyew as "contorted".

In United States $v$ Cruikshank, ${ }^{36}$ during a local election in the village of Colfax, Louisiana, a group of armed, White militia attacked and murdered over one-hundred freed African Americans. Only nine of the ninety-seven White defendants who were charged were eventually brought to trial and a mere three defendants were convicted of murder under the Enforcement Act. ${ }^{37}$ The United States Supreme Court, however,

28 Ibid.

29 The Civil Rights Act of 1875 is codified as 18 Stat 335-337.

30 Levin 2002: 232.

31 Lawrence 1999: 130.

32 Levin 2002: 232.

3380 US 581 (1872).

34 It should be noted that apart from being an early anti-discrimination law, the Civil Rights Act of 1866 (which has been referred to supra in n 18) also provided circuit courts with criminal and civil jurisdiction where persons were unable to enforce their constitutional rights in local and state courts. The right to testify in criminal proceedings was one of the constitutional rights envisaged by the act.

35 2002: 232.

3692 US $542(1876)$.

37 The Enforcement Act made conspiracy to deprive an individual of his constitutional rights (which included the right to peacefully assemble, the right to bear arms, the right to vote and the right to life) a felony. 
overturned all three convictions on the basis that the indictments were vague and general and had not specified that the victims were deprived of their constitutional rights on the basis of their race or colour. ${ }^{38}$

In United States $v$ Reese ${ }^{39}$ an election official in Kentucky was indicted under the Enforcement Act for refusing to register the vote of an African American in a municipal election. ${ }^{40}$ The Supreme Court held that the Fifteenth Amendment did not create a positive right to vote but the right to be free from discrimination on the basis of race, colour or servitude in the election process. Since section 3 of the Enforcement Act did not specify race, colour and servitude, the court held that Congress had exceeded the scope of the Fifteenth Amendment and that the section was therefore invalid. ${ }^{41}$

In United States $v$ Harris $^{42}$ it was held that the general prohibitions in the $\mathrm{Ku}$ Klux Klan Act against interfering with an individual's equal protection rights were too broad. No constitutional basis for federal-criminal jurisdiction existed in order to protect an individual from private conspiracies. This was a matter which fell within the jurisdiction of states. ${ }^{43}$

In the Civil Rights Cases $^{44}$ the United States Supreme Court invalidated the Civil Rights Act of 1875 . The case consolidated five separate cases that had been brought under the Civil Rights Act of 1875 by African Americans who had sued theatres, hotels and transit companies that had refused them admission. ${ }^{45}$ The court held that the Civil Rights Act of 1875 was unconstitutional since Congress had exceeded its powers under the Thirteenth and Fourteenth Amendments. The court ruled that the Thirteenth Amendment which prohibited slavery was not intended to eliminate the "badges of slavery" 46 such as discrimination in public accommodation. It was also held that the Fourteenth Amendment which dealt with the denial of equal protection by states was not applicable to private discriminatory acts by individuals, but only to discriminatory acts by the states and their officials.

The "contorted" reasoning present in the United States Supreme Court decisions persisted until the mid-twentieth century. In the case of Screws $v$ United States, ${ }^{47}$ Robert Hall, an African-American man, was brutally assaulted and murdered by, inter alia, the Sheriff, Deputy Sheriff and a police official in the town of Newton,

United States v Cruikshank 549-551.

92 US 214 (1876).

40 Section 3 of the Enforcement Act prohibited the wrongful refusal to register a vote.

41 United States $v$ Reese 215-218.

42106 US 629 (1882).

43 United States $v$ Harris 643-644. In hoc casu the court struck down the criminal provisions in sec 2 of the Ku Klux Klan Act.

44109 US 3 (1883).

45 The Civil Rights Act of 1875 has been described supra as one of the earliest federal antidiscrimination laws.

46 The expression "badges of slavery" historically referred to any markers or signifiers of slavery. See Mason-McAward 2012: 575-577.

47 325 US 91 (1945). 
Georgia. Since local authorities had failed to prosecute the perpetrators four months after the incident, the Federal Department of Justice instituted proceedings against the perpetrators under the Civil Rights Act of $1871 .{ }^{48}$ After all three defendants were convicted of murder in a federal court the United States Supreme Court ordered a retrial on the basis that the trial judge had not explained the meaning of "wilfully" to the defendants. The defendants had therefore not had a fair trial. The United States Supreme Court found that the defendants had misused their powers since they were acting in their official capacity or "under colour of law" when they arrested the victim. The prosecution under federal criminal civil-rights law was thus permissible. However, since the case concerned a "non-enumerated" right, all three defendants were acquitted. ${ }^{49}$

In his commentary on the Screws case, Cohen ${ }^{50}$ writes: "The arm of the Federal government, which was intended to protect Negro civil rights, was unduly weakened by its long struggle with the judiciary." According to Lawrence, ${ }^{51}$ the federal government gradually abandoned the prosecution of federal civil-rights crimes and entrusted states with the protection of minorities. Consequently the protections offered by the federal-criminal civil-rights statutes almost disappeared.

\section{The nineteen sixties to the nineteen nineties: The occasional use of federal-criminal civil-rights laws and the Civil Rights Act of 1968}

Pursuant to the United States Supreme Court's decision in Brown v Board of Education $^{52}$ which held that segregated schools were unconstitutional, African Americans began to assert their constitutional rights in what is commonly referred to as the Civil-Rights Movement. Despite the ruling in Brown v Board of Education, racist practices were commonplace in the United States of America. Such practices included segregated public facilities, discrimination in the provision of housing, discrimination in the armed forces and segregated public transportation. ${ }^{53}$ By the

48 The Civil Rights Act of 1871 (which has been referred to supra in $\mathrm{n} 21$ ) permitted the federal government to prosecute persons who conspired to deprive others of their civil rights or to prosecute any person acting "under colour of law" who willfully deprived persons of their rights" (in other words by any person who is a government agent).

49 According to Lawrence 1999: 39, there is no specific provision in the US Constitution of a right to be free from police brutality. It is thus an unspecified, non-enumerated right.

50 1946: 94.

51 1999: 126.

52347 US 483 (1954). In hoc casu, the segregation of White and African-American children in public schools was found to have a detrimental effect on African-American children, especially when sanctioned by the law. The case thus settled the issue that the "separate but equal" policy under segregationist laws affected African Americans unequally and unfairly. This case is regarded as having "set the stage" for the Civil-Rights Movement of the 1960s. See Dahlin 2012: 85.

53 Rhodes (accessed 23 Jan 2017). 
early nineteen sixties the Civil-Rights Movement was at its peak with race riots and mass social upheaval occurring across the United States of America. ${ }^{54}$

According to Rhodes, ${ }^{55}$ "[t] he 1960s would be marked by sit-ins (protests aimed at public places that refused to serve blacks), freedom rides (a form of protest aimed at desegregating interstate transportation), protest marches and ... voter registration projects". Lawrence ${ }^{56}$ writes that the assertion of civil rights by African Americans was met with racial violence that included murders, assaults, church arsons and bombings. Gerstenfeld ${ }^{57}$ similarly writes: "Once again, Black Americans striving for civil rights inspired thousands of White Americans to lash back". According to Perry, ${ }^{58}$ "[i]mages of police dispersing crowds with fire hoses or tear gas, missing and murdered civil-rights workers, Black, White, Jewish, Native American and Latino" were all part of the legacy of the Civil Rights Movement. The extensive media coverage of police brutality against anti-segregation demonstrators in Birmingham, Alabama and civil-rights workers in the South in 1963 influenced former President John F Kennedy's call for new civil-rights legislation. ${ }^{59}$

During the nineteen-sixties the federal government began to intervene in crimes that had been committed by state agents and private persons by resorting to the use of federal-criminal civil-rights statutes. ${ }^{60}$ This occurred in the case of United States $v$ Price $^{61}$ which arose out of the murders of three civil-rights workers by local lawenforcement officers and members of the Ku Klux Klan in the state of Mississippi. Since state law-enforcement officers had conspired with members of the Ku Klux Klan, the federal government intervened and charged the eighteen defendants with conspiracy to commit murder and of depriving the victims of numerous rights under the Enforcement Act and the Civil Rights Act of 1871. The court held that acting "under colour of law" does not necessarily involve only government agents. Since the other defendants had wilfully participated in joint activity with agents of the state they also had acted "under colour of law" in terms of the Civil Rights Act of $1871 .{ }^{62}$ Seven of the defendants were consequently convicted of conspiracy to commit murder and to deprive the victims of their Fourteenth Amendment rights to due process of law.

60 Belknap 1982: 474. According to Belknap, a serious deficiency in the justice systems in the Southern states was its persistent refusal to punish Whites for acts of violence against African Americans. The Police and Sheriff's Departments were often complicit in the violence. If the perpetrators were charged and tried, all-White juries acquitted them or found them guilty of less serious offences.

61383 US 787 (1966).

62 US v Price 794-795. 
One of the significant American laws that was passed at the end of the CivilRights Movement and which is regarded as a precursor of modern hate-crime laws is the Civil Rights Act of $1968 .{ }^{63}$ Although the act was not aimed directly at hate crimes, it is considered as a "catalyst for modern-hate crime legislation" ${ }^{64}$ The Civil Rights Act of 1968 prohibits interference with a person's federally-protected rights in cases of violence or threats of violence because of a person's race, colour, religion or national origin. ${ }^{65}$

The federally-protected rights include, inter alia, the rights to vote, to public education, to participation in jury service, to interstate travel and access to public places and services. Jacobs and Potter ${ }^{66}$ write that the act was intended to provide a remedy for the violence that resulted from opposition to civil-rights marches, to voter registration and voting issues, to the admission of African-American students to formerly all-White schools and universities and to efforts to abolish segregationist laws.

According to Wang, ${ }^{67}$ the Civil Rights Act of 1968 requires the defendant to have acted with a bias motive since it uses the words "because of" the victim's protected status and that prior to the creation of a purely federal hate-crime law, the federal government resorted to the use of this statute to prosecute hate crimes. The Civil Rights Act of 1968 also prohibits wilful interference or intimidation

63 Jacobs \& Potter 1998: 38.

64 Hall 2013: 24.

65 The Civil Rights Act of 1968 which is codified as 18 US $\$ 245$ (b)(2) provides: (b) "Whoever, whether or not acting under colour of law, by force or threat of force wilfully injures, intimidates, or interferes with, or attempts to injure, intimidate or interfere with- (2) any person because of his race, colour, national origin and because he is or has been- (a) enrolling in or attending any public school or public college; (b) participating in or enjoying any benefit, service, privilege, programme, facility, or activity provided or administered by any State or subdivision thereof; (c) applying for or enjoying employment, or any prerequisite thereof, by any private employer or any agency of any State or subdivision thereof, or joining or using the services or advantages of any labour organisation, hiring hall or employment agency; (d) serving, or attending upon any court of any State in connection with possible service as a grand or petit juror; of any common carrier by motor, rail, water, or air; (e) travelling in or using any facility of interstate commerce, or using any vehicle, terminal, or facility (f) enjoying the goods, services, facilities, privileges, advantages, or accommodations of any inn, hotel, motel, or other establishment which provides lodging to transient guests, or of any restaurant, cafeteria, lunchroom, lunch counter, soda fountain, or other facility which serves the public and which is principally engaged in selling food or beverages for consumption on the premises, or of any gasoline station, or of any motion picture house, theatre, concert hall, sports arena, stadium, or any other place of exhibition or entertainment which serves the public ... (s)hall be fined not more than $\$ 1000$, or imprisoned not more than one year, or both; and if bodily injury results shall be fined not more than $\$ 10000$, or imprisoned not more than ten years, or both; and if death results shall be subject to imprisonment for any term of years or for life." According to Woods 2008: 395, the Civil Rights Act of 1968 was enacted since local and state law-enforcement authorities were unable or unwilling to address racially motivated violence aimed at preventing minorities from exercising their constitutional and statutory rights.

66 1998: 38.

67 2000: 1401-1402. 
with a number of federally-protected activities including voting, serving as a juror, enjoying employment, attending school, using the facilities of interstate commerce or public facilities. ${ }^{68}$ The groups protected by the Civil Rights Act of 1968 include groups based on race, colour, religion and national origin since these were the victim groups most frequently targeted by White-supremacist organisations such as the $\mathrm{Ku}$ Klux Klan. ${ }^{69}$

The Civil Rights Act of 1968 places the onus on the prosecution to prove that the defendant was motivated by bias or prejudice and attacked the victim who was engaged in a federally-protected activity. However, the complicated nature of the act $^{70}$ and the high burden of proof required to secure convictions led to the emergence of state hate-crime laws in the United States of America with less onerous evidentiary requirements. $^{71}$

Several high-profile hate crimes were prosecuted under the Civil Rights Act of $1968 .{ }^{72}$ In the case of United States $v$ Lane, ${ }^{73}$ Alan Berg, a prominent Jewish radio talk-show host in Denver, Colorado, was murdered by members of a local hate group. The defendants were charged with violating the Civil Rights Act of 1968 in that they had wilfully injured and interfered with the victim because of his race and religion and because he was enjoying employment. ${ }^{74}$ The victim was well known for expressing his provocative views on radio about White right-wing groups. The defendants were all member of a right-wing group called "The Order". Using witness statements to prove the defendant's anti-Jewish sentiments, their desire to target prominent and powerful Jews in the media and their anger at the victim's antiright wing views which had been publicly declared on radio, the court found that the defendants disliked the manner in which the victim used his position on the radio to deride their beliefs. The defendants wanted to prevent the victim from continuing to perform his employment in a way that they considered offensive. On appeal, the defendants were found guilty of contravening the Civil Rights Act of 1968 and were sentenced to life imprisonment.

In United States $v$ Ebens $^{75}$ the defendant, Ron Ebens had killed Vincent Chin, an American of Chinese origin after an altercation which had commenced in a Detroit bar. Ebens pleaded guilty to manslaughter and was fined 3700 dollars and placed on probation. Following the huge public outcry and negative media coverage over the

68 Idem 1401.

69 Woods 2008: 394.

70 Which Jacobs \& Potter 1998: 38, describe as "abstruse".

71 Hall 2013: 114.

72 The Civil Rights Act of 1968 is regarded by some academics as the equivalent of the first federal hate-crime law, albeit one that was limited in scope. See, further, Woods 2008: 394 and Simmons 2012: 1878.

73883 F2d 1484 (1989).

74 The provisions of the Civil Rights Act 1968 have been provided supra in $\mathrm{n} 65$. Refer, in particular, to the provisions of 18 USC $\$ 245$ (b)(2)(c) in $n 65$.

75800 F2d 1422 (1986). 
leniency of the sentence, the Federal Department of Justice intervened and instituted proceedings against Ebens in a District Court under the Civil Rights Act of $1968^{76}$ since Chin had been enjoying the privileges and accommodation of a public bar which was a place of entertainment that was open to the public. Ebens was convicted of violating Chin's civil rights under the Civil Rights Act of 1968 since he had singled out Chin on account of his race and all the state witnesses testified about the racist statements made by the defendant during the altercation. ${ }^{77}$ On appeal, however, the judgement was overturned since Ebens had not been given a fair trial.

Wang ${ }^{78}$ contends that the Civil Rights Act of 1968 is a difficult statute to invoke in hate crimes since it requires that bias motivation has to be proved in order to fulfil the culpability requirements and that a victim's "enumerated right" had been interfered with or that the victim was engaged in a "federally-protected activity". This may often require the court to have to consider "trivial facts" ${ }^{79}$ In United States $v$ Baird ${ }^{80}$ for example, the court had to decide whether a "7-11" convenience store was a "place of public accommodation" under the Civil Rights Act of $1968 .{ }^{81}$ Since electronic video games were installed in the store, it was held that the store could be considered as a "place of entertainment" which the public could access and frequent. ${ }^{82}$ The assaults which occurred on the premises were thus prosecutable under federal civil-rights laws.

Despite the difficulties associated with the Civil Rights Act of 1968, Levin $^{83}$ writes that it was the most frequently-used federal-criminal civil-rights law.

In 1992 a federal-criminal civil-rights statute was used to prosecute the perpetrators who had assaulted Rodney King. Rodney King was an African American who had been brutally assaulted by four police officers from the Los Angeles Police Department. ${ }^{84}$ After all four police officers were acquitted of assault in the lower court widespread riots ensued in the city of Los Angeles ${ }^{85}$ The assault of King is regarded as a racially-motivated hate crime ${ }^{86}$ Federal prosecutors subsequently invoked the

76 The defendant was charged under 18 USC $\$ 245$ (b)(2)(f) which has been referred to supra in $\mathrm{n} 65$.

77 Ebens had made racist comments about both the Chinese and Japanese which suggested that he thought that Chin was Japanese. He also referred to foreign vehicle imports and blamed the Japanese for unemployment.

78 2000: 1402-1403.

79 Ibid.

$80 \quad 85$ F $3 d 450$ ( $9^{\text {th }}$ Cir 1996).

81 Refer to the provisions of the Civil Rights Act of 1968 in n 65 supra, and in particular to the provisions of 18 USC (b)(2)(f).

82 US v Baird 453.

83 2009: 7.

84 Koon v US 518 US (1996) at 81.

85 Koon v US 518 US (1996) at 83. The link between the Los Angeles riots and the acquittal of the four police officers has been made by Torres 2004: 231, Shenk 2004: 304 \& McDevitt et al 2004: 46.

86 Craig 2004: 64. Perry refers to widespread White supremacist activity being exposed in the Los Angeles Police Department during the investigations. See, further, Perry 2001: 221. 
provisions of one of the old federal-criminal civil-rights laws to prosecute the four police officers. ${ }^{87}$ In the subsequent trial, two of the four police officers were convicted of violating King's rights and received lengthy prison sentences. ${ }^{88}$

Despite the existence of numerous federal-criminal civil-rights statutes and the Civil Rights Act of 1968, such laws did not facilitate federal interventions in cases of hate crimes at state and local level. Moreover these laws were often difficult to prove since they required proof of bias motivation and that the victim's rights to use public accommodation or public facilities were interfered with or that the victim was engaged in a federally-protected activity such as voting, attending school or performing jury service. In this regard the former Attorney General of the United States, Janet Reno, stated as follows: "Federal civil rights laws make it more difficult to successfully prosecute the case than state law." ${ }^{\circ 9}$ Lawrence ${ }^{90}$ cites the example of the two African-American perpetrators who murdered a Jewish scholar during the Crown Heights Riots in New York. Federal prosecutors took two years to lay charges against the perpetrators due to the evidentiary burden of having to prove that they chose the victim because of his use of public facilities, which in this case consisted of a public street. ${ }^{11}$

Moreover, federal-criminal civil-rights laws and the Civil Rights Act of 1968 afforded protection to only a limited number of victim groups based on race, colour, national origin and religion. Since the second half of the twentieth century, other minority and victim groups, particularly women, gay men, lesbian women, and the disabled had begun asserting their rights and had come to the fore. Such groups were neither specifically mentioned in nor afforded protection by any of the statutes that were used to prosecute hate crimes.

\section{The twenty-first century: The enactment of a federal hate-crime law ${ }^{92}$}

The enactment of an American federal hate-crime law in 2009 can be attributed to the perpetration of two high-profile hate crimes eleven years earlier. In 1998, James Byrd Junior, an African-American man, was brutally assaulted and murdered by

87 Gerstenfeld 2013: 2-13. The Civil Rights Act of 1871 (which has been referred to supra in n 21) was invoked in this case. The Civil Rights Act of 1871 prohibits depriving a citizen of his rights or privileges "under colour of law". Since the four police officers were acting in their official capacity, they were acting "under colour of law".

88 Koon v US 518 US (1996) at 82-83.

89 Janet Reno quoted in Lawrence 2008: 275.

90 2008: 276.

91 Ibid.

92 Since this submission focuses on the historical prosecution of hate crimes, the federal hate-crime law that was passed in 2009 will only be discussed briefly. 
White supremacists. ${ }^{93}$ In the same year, Matthew Shepard, a gay university student, was lured from a bar by two men who pretended to be gay, assaulted, tied to a fence and left to die in sub-zero temperatures. ${ }^{94}$ Both murders increased public pressure for stricter federal hate-crime legislation..$^{95}$ Despite several efforts to introduce a new federal hate-crime law, the proposed law was met with fierce opposition in the Conservative-led House of Representatives. ${ }^{96}$ After ten years of Congressional debates, a new federal hate-crime law, the Matthew Shepard and James Byrd Junior Hate Crimes Prevention Act ${ }^{97}$ was eventually signed into law by President Barack Obama in late 2009.98

The Matthew Shepard Act provides that the Attorney General of the United States of America may, at the request of state, local or tribal law-enforcement authorities, provide financial, technical, prosecutorial or any other form of assistance in the criminal investigation or prosecution of any crime of violence that constitutes a felony under state, local or tribal law and that is motivated by prejudice based on the actual or perceived race, colour, religion, national origin, gender, sexual orientation, gender identity, or disability of the victim. ${ }^{99}$ The Attorney General of the United States of America is empowered to award financial grants to state, local or tribal authorities upon application by the latter, in order to assist in the investigation and prosecution of hate crimes in their respective jurisdictions. ${ }^{100}$

The Matthew Shepard Act is regarded as an improvement on the Civil Rights Act of 1968 which had hitherto been the most important federal statute to prosecute hate crimes, since it removed the requirement that the victim had to have been engaged in a federally-protected activity or that a victim's federally-protected rights had been interfered with. ${ }^{101}$ The positive effects of the Matthew Shepard Act's funding and resource provisions are summed up by Woods who writes that the act

93 Husselbee \& Elliott 2002: 834.

94 Idem 835. See, further, The Matthew Shepard Act (accessed 6 Feb 2017).

95 Jackson (accessed 6 Feb 2017) and Chorba 2001: 322.

96 Coker 2011: 282. Opposition to the proposed hate-crime law in the House of Representatives stemmed from the fact that the law would have extended protection to gay men and lesbian women.

97 Hereafter referred to by its short title, the Matthew Shepard Act.

98 Weiner (accessed 5 Feb 2017). The Matthew Shepard Act is codified in various sections of the United States Code as 18 USC $\$ 249$.

99 According to sec 4 (a)(1) of the Matthew Shepard Act. According to Eric Holder (2010), former Attorney General of the USA, some states and local authorities do not possess the funds, resources and technology to investigate hate crimes. The act consequently allows the federal government which has greater capacity and a larger network to assist in the investigations and prosecutions. See, further, testimony by Eric Holder 2010: 18.

100 Section 4(b) 1-3 of the Matthew Shepard Act.

101 Henderson 2010: 67-168. As was discussed earlier in this article, these requirements placed an onerous evidentiary burden on the prosecution in hate-crime cases and led to delays in prosecutions. 
has the potential to substantially eliminate the failures of state and local authorities to classify and investigate hate crimes because of a lack of resources. ${ }^{102}$

However, the need for a federal hate-crime law has been questioned by Chorba who found no evidence of state default in the prosecution of hate crimes. ${ }^{103}$ As has already been discussed in this article, the most important reason for the enactment of federal-criminal civil-rights statutes in the nineteenth century was the default of states in the investigation and prosecution of racially-motivated crimes. While Lawrence ${ }^{104}$ concedes that the overt forms of state default that existed in the past may no longer exist today, there are still "systemic factors" at state level that call for a federal hate-crime law. According to Lawrence, ${ }^{105}$ racially-motivated hate-crime cases are often politicised and if prosecuted at state level they would have to be prosecuted by elected District Attorneys and a local jury. In the case of a federal prosecution, however, the case would be brought by an appointed United States Attorney and heard by a federal jury appointed from a broad cross-section of federal judicial districts. ${ }^{106}$ The role players in a federal prosecution are thus largely immune from local politics. ${ }^{107}$

\section{Conclusion}

While the necessity of an American federal hate-crime law has been questioned, it is submitted that a law which includes a criminal sanction may be considered as the ultimate "symbolic message" that a government has at its disposal to try and change prejudiced attitudes and behaviour. ${ }^{108}$ Hate-crime laws are therefore regarded as highly symbolic laws ${ }^{109}$ which are intended to convey a government's denunciation

102 Woods 2008: 423. Refer, eg, to the case of United States v Beebe, Case No 1:10-cr-03104 BB (US District Court for the District of New Mexico) which was one of the earliest prosecutions to be brought under the Matthew Shepard Act. The case involved the racially-motivated assault of a Native-American man. The case illustrates how federal, state and local authorities co-operated in the investigation and successful prosecution of the crime.

103 See Chorba 2001: 345-346. He refers to the inability of former Attorney General Eric Holder to cite actual examples of state default in the prosecution of hate crimes in congressional hearings on the Matthew Shepard Act. He also cites the example of the Matthew Shepard murder where local and state prosecutors sought the strongest penalties available under the existing criminal law since the state of Wyoming did not have a hate-crime law that covered sexual orientation. See, further, Chorba 2001: 349-351. He also refers to the murder of James Byrd. In the investigation of this murder, prosecutors in Texas had obtained death sentences for both White-supremacist murderers in the absence of a Texas hate-crime law. See, also, Chorba 2001: 351.

104 Lawrence 1998-2000: 163.

105 Idem 164.

106 Ibid.

107 Ibid.

108 Hall 2013: 124.

109 Ibid. 
of criminal conduct that is motivated by certain prejudices. ${ }^{110}$ Lawrence ${ }^{111}$ advocates for federal hate-crime laws since hate crimes, and particularly those hate crimes that are racially-motivated, impinge on the commitment to equality which is one of the most sacrosanct American values. According to Lawrence, ${ }^{112}$ racial inequality was the reason for the American Civil War and the subsequent constitutional amendments. Racial inequality was also the catalyst for the Civil-Rights Movement later in the twentieth century. According to Lawrence,${ }^{113}$ hate crimes are therefore a violation of the national social contract of equality and this is the main prudential reason for the enactment of federal hate-crime laws in the United States of America.

\section{BIBLIOGRAPHY}

Belknap, MR (1982) “The legal legacy of Lemuel Penn” Howard Law J 25: 467-524

Bradley, Curtis A (1998) “The Treaty Power and American Federalism” Michigan Law Rev 97(2): $390-461$

Chorba, Christopher (2001) "The danger of federalizing hate crimes: Congressional misconceptions and unintended consequences of the Hate Crime Prevention Act" Virginia Law Rev 87: 319379

Cohen, Julius (1946) "The Screws Case: Federal protection of Negro rights" Columbia Law Rev 46: $94-106$

Coker, Carter T (2011) "Hope-fulfilling or effectively chilling? Reconciling the Hate Crimes Prevention Act with the First Amendment" Vanderbilt Law Rev 64: 271-299

Craig, Kellina M (2004) "Retaliation, fear or rage: An investigation of African-American and White reactions to racist hate crimes" in Gerstenfeld, Phyllis B \& Grant, Diana R (eds) Crimes of Hate: Selected Readings (Thousand Oaks, Calif): 58-66

Dahlin, Donald C (2012) We the People: A Brief Introduction to the Constitution and its Interpretation (New York, NY)

Gerstenfeld, Phyllis B (2013) Hate Crimes: Causes, Controls and Controversies 3rd ed (Thousand Oaks, Calif)

Hall, Nathan (1998) Footnote Hall 1998: 20

Hall, Nathan (2013) Hate Crime 2 ed (Abingdon)

Henderson, Elizabeth K (2010) "Offended sensibilities: Three reasons why the Hate Crimes Prevention Act of 2009 is a well-intended misstep" Chapman Law Rev 2: 163-195

Holder, Eric (2010) Hearings before the Committee on the Judiciary: United States Senate. $11^{\text {th }}$ Congress, June 252009 (Washington DC)

110 Walters 2013: 1.

111 1998-2000: 164.

112 Ibid.

113 Ibid. 
Husselbee, Paul L \& Elliott, Larry (2002) "Looking beyond hate: How national and regional newspapers framed hate crimes in Jasper, Texas and Laramie, Wyoming" Journalism and Mass Communication Quarterly 79: 833-852

Jackson, D (accessed 6 Feb 2017) "Obama signs the hate crime law rooted in crimes of 1998" available at $h t t p: / / w w w . U S A T o d a y . c o m / c o m m u n i t i e s / t h e o v a l / p o s t / 2009 / 10 / 620000629 / 1$

Jacobs, James B \& Potter, Kimberley (1998) Hate Crimes, Criminal Law and Identity Politics (New York, NY)

Kelly, Robert J (1998) "The Ku Klux Klan: Recurring hate in America” in Kelly, Robert J \& Maghan, Jess (eds) Hate Crime: The Global Politics of Polarization (Carbondale, Ill): 51-83

Lawrence, Frederick M (1999) Punishing Hate: Bias Crimes under American Law (Cambridge, Mass)

Lawrence, Frederick M (1998-2000) “The case for a federal bias-crime law” National Black Law $J$ 10(16): 144-168

Lawrence, Frederick M (2008) "The evolving Federal role in bias-crime law enforcement and the Hate Crime Prevention Act of 2007" Stanford Law and Policy Rev 19(2): 251-282

Levin, Brian (2002) "From slavery to hate-crime laws: The emergence of race and status-based protection in American criminal law" J of Social Issues 58(2): 227-245

Levin, Brian (2009) "The long arc of justice: Race, violence and the emergence of hate crime law" in Perry, Barbara (ed) et al Hate Crimes vol 1 (Westport, Conn): 1-22

Mason McAward, Jennifer (2012) "Defining the badges and incidents of slavery" J of Constitutional Law 14(3): 561-630

McDevitt, Jack et al (2004) "Consequences for victims: A comparison of bias and non-biasmotivated assaults" in Gerstenfeld, Phyllis B \& Grant, Diana R (eds) Crimes of Hate: Selected Readings (Thousand Oaks, Calif): 45-57

Meese, Ed (1997) "Big brother on the beat: The expanding federalization of crime" Texas Rev of Law and Politics 1: 1-23

Perry, Barbara (2001) In the Name of Hate: Understanding Hate Crimes (New York, NY)

Petrosino, Carolyn (1999) "Connecting the past to the future: Hate crime in America" $J$ of Contemporary Criminal Justice 15(1): 22-47

Rhodes, HA (accessed 23 Jan 2017): "An analysis of the Civil Rights Act of 1964: A legislative response to racial discrimination in the USA" available at http://www.yale.edu/ynhti/ curriculum/units/1982/3/82.03.04.x.html

Riker, William H (1955) “The Senate and American federalism” American Political Science Rev 49(2): 452-469

Sheldon, Charles H (2002) Essentials of the American Constitution: The Supreme Court and the Fundamental Law (Boulder, Colo)

Shenk, Alyssa (2004) "Victim-offender mediation: The road to repairing hate crime injustice" in Gerstenfeld, Phyllis B \& Grant, Diana R (eds) Crimes of Hate: Selected Readings (Thousand Oaks, Calif): 299-309

Shimamoto, Eric (2003-2004) "Rethinking hate crime in the age of terror" University of MissouriKansas City LR 72: 829-843

Simmons, Kami C (2012) "Subverting symbolism: The Matthew Shepard and James Byrd Jr. Hate Crimes Prevention Act and co-operative federalism" American Criminal Law Rev 49: 1863-1912 
"The Matthew Shepard Act" (accessed 6 Feb 2017) available at http://www.nytimes. com/2009/05/06/opinion/06wed3.html?

Torres, Sam (2004) "Hate crimes against African Americans: The extent of the problem" in

Gerstenfeld, Phyllis B \& Grant, Diana R (eds) Crimes of Hate: Selected Readings (Thousand Oaks, Calif): 225-235

Walters M (2013) “Conceptualizing 'hostility' for hate-crime law: Minding the 'minutiae' when interpreting section 28(1)(a) of the Crime and Disorder Act 1998" Oxford J of Legal Studies: $1-28$

Wang, Lu-In (2000) "Recognising opportunistic bias crimes" Boston University Law Rev 80: 1399-1435

Weiner, R (accessed 5 Feb 2017) "Hate crimes bill signed into law 11 years after Shepard's death" available at http://www.huffingtonpost.com/2009/10/28/hate-crimes-bill-to-be-signed 336883.html

Woods, Jordan B (2008) "Ensuring a right of access to the courts for bias-crime victims: A section 5 defence of the Matthew Shepard Act" Chapman Law Rev 12: 389-431

Zimmerman, Joseph F (1992) Contemporary American Federalism: The Growth of the National Power (Leicester)

\section{Legislation}

Revised Statute of Kentucky of 1860

The Civil Rights Act of 1866 (codified as 14 Stat 27-30)

The Civil Rights Act of 1871 (codified as 17 Stat 31)

The Civil Rights Act of 1875 (codified as 18 Stat 335-337)

The Civil Rights Act of 1968 (codified as 18 USC §245 (b)(2))

The Constitution of the United States of America. Fifteenth Amendment (1870)

The Constitution of the United States of America. Fourteenth Amendment (1868)

The Constitution of the United States of America. Thirteenth Amendment (1865)

The Constitution of the United States of America. Tenth Amendment (1791)

The Enforcement Act of 1870 (codified as 16 Stat 140)

The Ku Klux Klan Act of 1871 (codified as 17 Stat 31)

The Matthew Shepard and James Byrd Junior Hate Crimes Prevention Act of 2009 (codified in various sections of the United States Code as 18 USC §249)

\section{Case law}

Blyew v United States 80 US 581 (1872)

Brown v Board of Education 347 US 483 (1954)

Brown v Board of Education 347 US 483 (1954)

Civil Rights Cases 109 US 3 (1883)

Koon v US 518 US (1996)

Screws $v$ United States, 325 US 91 (1945) 


\section{KAMBAN NAIDOO}

United States $v$ Baird 85 F 3d $450\left(9^{\text {th }}\right.$ Cir 1996)

United States $v$ Beebe Case No 1:10-cr-03104 BB (US District Court for the District of New Mexico)

United States v Cruikshank 92 US 542 (1876)

United States $v$ Ebens 800 F2d 1422 (1986)

United States $v$ Harris 106 US 629 (1882)

United States $v$ Lane 883 F2d 1484 (1989)

United States v Price 383 US 787 (1966)

United States $v$ Reese 92 US 214 (1876) 